Article

\title{
Dimensional Control in Polyoxometalate Crystals Hybridized with Amphiphilic Polymerizable Ionic Liquids
}

\author{
Toshiyuki Misawa ${ }^{1}$, Jun Kobayashi ${ }^{1}$, Yoshiki Kiyota ${ }^{1}$, Masayuki Watanabe ${ }^{2}$, Seiji Ono ${ }^{2}$, \\ Yosuke Okamura $^{2}$, Shinichi Koguchi ${ }^{1}$, Masashi Higuchi ${ }^{2}$, Yu Nagase ${ }^{2}$ and Takeru Ito ${ }^{1, *(D)}$ \\ 1 Department of Chemistry, School of Science, Tokai University, 4-1-1 Kitakaname, Hiratsuka 259-1292, Japan \\ 2 Department of Applied Chemistry, School of Engineering, Tokai University, 4-1-1 Kitakaname, \\ Hiratsuka 259-1292, Japan \\ * Correspondence: takeito@keyaki.cc.u-tokai.ac.jp; Tel.: +81-463-58-1211 (ext. 3737)
}

Received: 19 June 2019; Accepted: 15 July 2019; Published: 16 July 2019

\begin{abstract}
Ionic liquids are an important component for constructing functional materials, and polyxometalate cluster anion is a promising partner for building inorganic-organic hybrid materials comprising ionic liquids. In such hybrid materials, the precise control of the molecular arrangement in the bulk structures is crucial for the emergence of characteristic functions, which can be realized by introducing an amphiphilic moiety into the ionic liquids. Here, an amphiphilic polymerizable imidazolium ionic liquid with a methacryloyl group was firstly hybridized with polyoxometalate anions of octamolybdate $\left(\left[\mathrm{Mo}_{8} \mathrm{O}_{26}\right]^{4-}, \mathrm{Mo}_{8}\right)$ and silicotungstate $\left(\left[\mathrm{SiW}_{12} \mathrm{O}_{40}\right]^{4-}, \mathrm{SiW}_{12}\right)$ to obtain inorganic-organic hybrid crystals. The polymerizable ionic liquid with a octyl chain (denoted as $\mathrm{MAImC}_{8}$ ) resulted in the formation of anisotropic molecular arrangements in the bulk crystal structure, which was compared with the hybrid crystals composed from the polymerizable ionic liquid without a long alkyl chain (denoted as MAIm). Rather densely packed isotropic molecular arrangements were observed in the hybrid crystals of MAIm- $\mathrm{Mo}_{8}$ and $\mathrm{MAIm}-\mathrm{SiW}_{12}$ due to the lack of the amphiphilic moiety. On the other hand, using the amphiphilic $\mathrm{MAImC}_{8}$ cation gave rise to a honeycomb-like structure with the $\mathrm{Mo}_{8}$ anion and a layered structure with the $\mathrm{SiW}_{12}$ anion, respectively.
\end{abstract}

Keywords: inorganic-organic; hybrid crystal; ionic liquid; amphiphilic; polyoxometalate

\section{Introduction}

Ionic liquid molecules attract extensive attention from researchers owing to their characteristic properties such as conductivity, catalysis, and separation abilities [1-11]. These properties are quite attractive for the construction of functional materials. The hybridization of ionic liquids as organic components with other inorganic counter parts is effective for building up functional inorganic-organic hybrid materials. To select inorganic counter parts for the hybridization is crucial for improving the thermal stability and other properties.

Polyoxometalate $(\mathrm{POM})$ cluster anions are effective inorganic components for constructing inorganic-organic hybrid materials due to their characteristic physicochemical properties [12-20]. Hybridization of ionic liquids with POMs has been investigated, and several functional hybrids have been successfully realized such as solid electrolytes or catalysts [21-28]. These ionic liquid-POM hybrids sometimes have POM arrangements in a disordered manner, which may be a drawback for exploiting their characteristics in solid-state hybrid materials. The dimensional control of the components in the solid state is quite significant for the emergence and control of characteristic properties [29]. Introducing amphiphilic moieties, such as a long alkyl chain [30-36] in ionic liquids 
is an effective way of constructing single-crystalline ordered structures in the ionic liquid-POM hybrids [37-41].

Recently, we designed a polymerizable ionic liquid cation with an imidazolium moiety with a

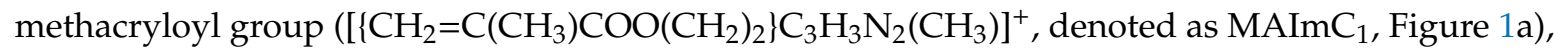
and successfully synthesized inorganic-organic hybrid monomers and polymers with several POM anions [42-44]. These MAImC ${ }_{1}-\mathrm{POM}$ hybrids were isolated as single crystals with clarified structures, and behaved as monomers of hybrid polymers exhibiting high conductivity as solid electrolytes [44]. In the MAImC $\mathrm{C}_{1}-\mathrm{POM}$ hybrid monomers, the POM arrangements in the bulk crystal structures were isotropic due to the small molecular size of the MAImC $\mathrm{M}_{1}$ cation. Introducing an amphiphilic moiety into MAImC $\mathrm{C}_{1}$ will give rise to a more anisotropic molecular arrangement of POM anions derived from the structure-directing ability of the amphiphilic moiety [30-32].

Here we report the first syntheses of POM hybrid crystals with amphiphilic polymerizable ionic liquids. The amphiphilic polymerizable ionic liquid is a $\mathrm{MAImC}_{1}$ derivative with a long octyl chain instead of a methyl group $\left(\left[\left\{\mathrm{CH}_{2}=\mathrm{C}\left(\mathrm{CH}_{3}\right) \mathrm{COO}\left(\mathrm{CH}_{2}\right)_{2}\right\} \mathrm{C}_{3} \mathrm{H}_{3} \mathrm{~N}_{2}\left(\mathrm{C}_{8} \mathrm{H}_{17}\right)\right]^{+}\right.$, denoted as $\mathrm{MAImC}_{8}$, Figure 1a). Another $\mathrm{MAImC}_{1}$ derivative without a methyl group $\left(\left[\left\{\mathrm{CH}_{2}=\mathrm{C}\left(\mathrm{CH}_{3}\right) \mathrm{COO}\left(\mathrm{CH}_{2}\right)_{2}\right\} \mathrm{C}_{3} \mathrm{H}_{4} \mathrm{~N}_{2}\right]^{+}\right.$, denoted as MAIm, Figure 1a) was also utilized to hybridize with POM anions for comparison. The POM anions hybridized were $\beta$-type octamolybdate $\left(\left[\mathrm{Mo}_{8} \mathrm{O}_{26}\right]^{4-}\right.$ $\left(\mathrm{Mo}_{8}\right)$, Figure $\left.1 \mathrm{~b}\right)$ and dodecatungstosilicate $\left(\left[\mathrm{SiW}_{12} \mathrm{O}_{40}\right]^{4-}\left(\mathrm{SiW}_{12}\right)\right.$, Figure $\left.1 \mathrm{~b}\right)$, both of which are anions with a 4- charge. Hybrid crystals with $\mathrm{Mo}_{8}$ and $\mathrm{SiW}_{12}$ have been reported previously [42,44]. The hybrid crystals with $\mathrm{MAImC}_{8}$ contained anisotropic arrangements of POM anions in their bulk crystal structures due to the presence of an amphiphilic moiety, while hybrid crystals with MAIm exhibited isotropic POM arrangements.

(a)<smiles>C=C(C)C(=O)OCCn1cc[n+](C)c1</smiles><smiles></smiles>

(b)
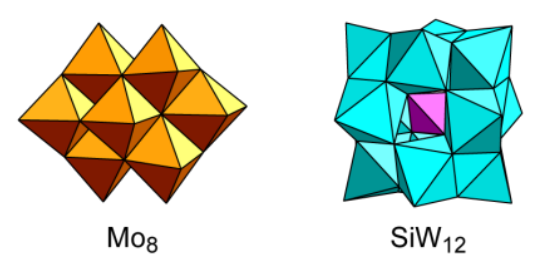

Figure 1. Molecular structures of the components: (a) polymerizable ionic liquids of MAImC ${ }_{1}$, $\mathrm{MAImC}_{8}$, and MAIm; (b) polyoxometalates of $\beta$-type octamolybdate $\left(\mathrm{Mo}_{8}\right)$ and dodecatungstosilicate $\left(\mathrm{SiW}_{12}\right)$ anions.

\section{Materials and Methods}

\subsection{Materials and General Methods}

All chemical reagents were purchased from FUJIFILM Wako Pure Chemical Corporation (Osaka, Japan) and Tokyo Chemical Industry Co., Ltd. (TCI, Tokyo, Japan). The starting polymerizable ionic liquid of $\left[\left\{\mathrm{CH}_{2}=\mathrm{C}\left(\mathrm{CH}_{3}\right) \mathrm{COO}\left(\mathrm{CH}_{2}\right)_{2}\right\} \mathrm{C}_{3} \mathrm{H}_{3} \mathrm{~N}_{2}\right]$ (denoted as MAIm-N) was synthesized as a neutral 
compound, and $\left[\left\{\mathrm{CH}_{2}=\mathrm{C}\left(\mathrm{CH}_{3}\right) \mathrm{COO}\left(\mathrm{CH}_{2}\right)_{2}\right\} \mathrm{C}_{3} \mathrm{H}_{3} \mathrm{~N}_{2}\left(\mathrm{C}_{8} \mathrm{H}_{17}\right)\right] \mathrm{Br}\left(\mathrm{MAImC} \mathrm{C}_{8} \cdot \mathrm{Br}\right)$ were synthesized as bromide salts according to previous studies (Figure S1) [42-44].

Infrared (IR) spectra were recorded on a Jasco FT/IR-4200ST spectrometer (JASCO Corporation, Tokyo, Japan) by the KBr pellet method. Powder X-ray diffraction (XRD) patterns were measured with a Rigaku MiniFlex300 diffractometer (Rigaku Corporation, Tokyo, Japan) by using $\mathrm{Cu} \mathrm{K} \alpha$ radiation $(\lambda=1.54056 \AA)$ at ambient temperature. CHN (carbon, hydrogen, and nitrogen) elemental analyses were performed with a PerkinElmer 2400II elemental analyzer (PerkinElmer, Waltham, MA, USA).

\subsection{Syntheses of Polyoxometalate Hybrids with Polymerizable Ionic Liquids}

\subsubsection{Synthesis of MAIm-Mo8}

As-prepared MAIm- $\mathrm{Mo}_{8}$ (denoted as $\mathbf{1}$ ) was initially precipitated by a cation exchange reaction. $\mathrm{Na}_{2} \mathrm{MoO}_{4} \cdot 2 \mathrm{H}_{2} \mathrm{O}(1.0 \mathrm{~g}, 4.1 \mathrm{mmol})$ was dissolved in $10 \mathrm{~mL}$ of $\mathrm{H}_{2} \mathrm{O}$, and then the $\mathrm{pH}$ was adjusted to 3.8 by $6 \mathrm{M} \mathrm{HCl}$. To the obtained homogeneous solution was added an ethanol solution (10 mL) of MAIm-N $(0.28 \mathrm{~g}, 1.6 \mathrm{mmol})$ neutralized by $1 \mathrm{M} \mathrm{HCl}(2.0 \mathrm{~mL})$. The resulting suspension was filtered to obtain colorless precipitates, which was dried under ambient atmosphere to obtain colorless precipitates ( $0.73 \mathrm{~g}$, yield: $48 \%)$. An acetonitrile/ethanol solution $(20 \mathrm{~mL}, 1: 1(v / v))$ of as-prepared $\mathbf{1}(0.03 \mathrm{~g})$ was heated at ca. $343 \mathrm{~K}$ for $3 \mathrm{~h}$, and then the supernatant was slowly evaporated at room temperature to obtain colorless plates of $\mathbf{1}$. CHN elemental analysis: Calcd for $\mathrm{C}_{30} \mathrm{H}_{45} \mathrm{~N}_{6} \mathrm{NaMo}_{8} \mathrm{O}_{32}$ : C: $18.53, \mathrm{H}: 2.25$, N: 4.80\%. Found: C: 18.97, H: 2.30, N: 4.98\%. IR (KBr disk): $3144(w), 3109$ (w), $3010(w), 2979(w), 2927$ $(\mathrm{w}), 2883(\mathrm{w}), 1734(\mathrm{~m}), 1718(\mathrm{~m}), 1635(\mathrm{~m}), 1577(\mathrm{w}), 1543(\mathrm{w}), 1456(\mathrm{w}), 1401(\mathrm{w}), 1362(\mathrm{w}), 1317(\mathrm{w})$, $1301(\mathrm{~m}), 1170(\mathrm{~m}), 1086(\mathrm{w}), 1041(\mathrm{w}), 942(\mathrm{~s}), 916(\mathrm{~s}), 846(\mathrm{~m}), 817(\mathrm{w}), 724(\mathrm{~s}), 666(\mathrm{~m}), 626(\mathrm{w}), 556(\mathrm{w})$, $523(\mathrm{w}) \mathrm{cm}^{-1}$.

\subsubsection{Synthesis of $\mathrm{MAImC}_{8}-\mathrm{Mo}_{8}$}

As-prepared $\mathrm{MAImC}_{8}-\mathrm{Mo}_{8}$ (denoted as 2) was synthesized and recrystallized by a similar procedure to $1 . \mathrm{Na}_{2} \mathrm{MoO}_{4} \cdot 2 \mathrm{H}_{2} \mathrm{O}(0.51 \mathrm{~g}, 2.1 \mathrm{mmol})$ dissolved in $10 \mathrm{~mL}$ of $\mathrm{H}_{2} \mathrm{O}$ was adjusted to $\mathrm{pH} 3.8$ by $6 \mathrm{M} \mathrm{HCl}$, and then an ethanol solution $(10 \mathrm{~mL})$ of $\mathrm{MAImC}_{8} \cdot \mathrm{Br}(0.30 \mathrm{~g}, 0.80 \mathrm{mmol})$ was added. The resulting suspension was filtered and dried to obtain colorless precipitates ( $0.38 \mathrm{~g}$, yield: $47 \%)$. An acetonitrile/ethanol solution $(20 \mathrm{~mL}, 1: 1(v / v))$ of as-prepared $2(0.03 \mathrm{~g})$ was heated at ca. $343 \mathrm{~K}$ for 3 hours, and the supernatant was slowly evaporated at room temperature to obtain colorless plates of 2. $\mathrm{CHN}$ elemental analysis: Calcd for $\mathrm{C}_{51} \mathrm{H}_{87} \mathrm{~N}_{6} \mathrm{NaMo}_{8} \mathrm{O}_{32}$ : C: $29.10, \mathrm{H}: 4.26, \mathrm{~N}: 3.99 \%$. Found: $\mathrm{C}$ : 28.05, H: 4.14, N: 3.52\%. IR (KBr disk): 3136 (w), 3105 (w), 2956 (m), 2925 (s), 2854 (m), 1719 (m), 1636 (w), $1560(\mathrm{w}), 1457(\mathrm{w}), 1404(\mathrm{w}), 1377(\mathrm{w}), 1362(\mathrm{w}), 1317(\mathrm{w}), 1296(\mathrm{w}), 1162(\mathrm{~m}), 1039(\mathrm{w}), 943(\mathrm{~s}), 913$ (s), $844(\mathrm{~m}), 714(\mathrm{~s}), 666(\mathrm{~m}), 555(\mathrm{w}), 525(\mathrm{w}), 473(\mathrm{w}), 453(\mathrm{w}), 442(\mathrm{w}), 416(\mathrm{w}) \mathrm{cm}^{-1}$.

\subsubsection{Synthesis of MAIm-SiW 12}

As-prepared MAIm-SiW 12 (denoted as 3) was synthesized by adding a $10 \mathrm{~mL}$ ethanol solution containing MAIm-N (0.59 g, $3.3 \mathrm{mmol})$ to a $10 \mathrm{~mL}$ ethanol solution of dodecatungstosilicic acid 26 hydrate $\left(\mathrm{H}_{4}\left[\mathrm{SiW}_{12} \mathrm{O}_{40}\right] \cdot 26 \mathrm{H}_{2} \mathrm{O}\left(\mathrm{H}-\mathrm{SiW}_{12}\right), 2.0 \mathrm{~g}(0.60 \mathrm{mmol})\right)$. The obtained suspension was separated by decantation to obtain colorless precipitates, which were washed by water and dried under ambient atmosphere (1.3 g, yield: 51\%). A 1,4-dioxane solution $(20 \mathrm{~mL})$ of as-prepared $3(0.03 \mathrm{~g})$ was heated at ca. $333 \mathrm{~K}$ for $3 \mathrm{~h}$, and the supernatant was kept at $298 \mathrm{~K}$ to obtain colorless plates of 3 . CHN elemental analysis: Calcd for $\mathrm{C}_{36} \mathrm{H}_{52} \mathrm{~N}_{8} \mathrm{SiW}_{12} \mathrm{O}_{48}$ : C: $12.01, \mathrm{H}: 1.46, \mathrm{~N}: 3.11 \%$. Found: C: $12.03, \mathrm{H}: 1.47, \mathrm{~N}: 3.04 \%$. IR (KBr disk): $3145(\mathrm{w}), 3072(\mathrm{w}), 2963(\mathrm{w}), 2927(\mathrm{w}), 1715(\mathrm{~m}), 1634(\mathrm{w}), 1578(\mathrm{w}), 1547(\mathrm{w}), 1449(\mathrm{w})$, $1404(\mathrm{w}), 1319(\mathrm{w}), 1297(\mathrm{w}), 1168(\mathrm{~m}), 1085(\mathrm{w}), 1013(\mathrm{w}), 973$ (s), $922(\mathrm{~s}), 884(\mathrm{w}), 796(\mathrm{~s}), 665(\mathrm{w}), 622$ (w), $534(w) \mathrm{cm}^{-1}$. 


\subsubsection{Synthesis of $\mathrm{MAImC}_{8}-\mathrm{SiW}_{12}$}

As-prepared $\mathrm{MAImC}_{8}-\mathrm{SiW}_{12}$ (denoted as 4 ) was synthesized and recrystallized by a similar procedure to 3 . $\mathrm{H}-\mathrm{SiW}_{12}(1.2 \mathrm{~g}, 0.36 \mathrm{mmol})$ was dissolved in $5 \mathrm{~mL}$ of ethanol, and then an ethanol solution $(10 \mathrm{~mL})$ of $\mathrm{MAImC}_{8} \cdot \mathrm{Br}(0.50 \mathrm{~g}, 1.3 \mathrm{mmol})$ was added. The resulting suspension was filtered and dried under ambient atmosphere to obtain colorless precipitates (1.2 g, yield: $69 \%$ ). An 1,4-dioxane/ethanol solution $(20 \mathrm{~mL}, 1: 1(v / v))$ of as-prepared $4(0.03 \mathrm{~g})$ was heated at ca. $333 \mathrm{~K}$ for 3 hours, and the supernatant was kept at $298 \mathrm{~K}$ to obtain colorless plates of 4 . $\mathrm{CHN}$ elemental analysis: Calcd for $\mathrm{C}_{68} \mathrm{H}_{116} \mathrm{~N}_{8} \mathrm{SiW}_{12} \mathrm{O}_{48}$ : C: 19.50, H: 2.79, N: 2.74\%. Found: C: 20.18, H: 2.89, N: 2.77\%. IR (KBr disk): $3142(\mathrm{w}), 3109$ (w), $2957(\mathrm{w}), 2925(\mathrm{~m}), 2853(\mathrm{~m}), 1719(\mathrm{w}), 1635$ (w), $1561(\mathrm{w}), 1457(\mathrm{w}), 1401(\mathrm{w})$, $1377(w), 1359(w), 1318(w), 1295(w), 1161(w), 1107(w), 1054(w), 1013(w), 973(m), 920(s), 884(w)$, $795(\mathrm{~s}), 653(\mathrm{w}), 530(\mathrm{w}), 487(\mathrm{w}), 423(\mathrm{w}) \mathrm{cm}^{-1}$.

\subsection{X-ray Crystallography}

Single crystal X-ray diffraction measurements for 1-3 were performed with an ADSC Q210 CCD area detector by using synchrotron radiation $(\lambda=0.60000-0.80000 \AA$, Table 1$)$ at 2D beamline in the Pohang Accelerator Laboratory (PAL, a synchrotron radiation facility in Pohang, Republic of Korea). The processing of both diffraction images and absorption correction were performed with HKL3000 [45]. The diffraction measurements for 4 were made on a Rigaku XtaLAB P200 diffractometer (Rigaku Corporation, Tokyo, Japan) using graphite monochromated Mo K $\alpha$ radiation, and the data were collected and processed using CrysAlisPro [46]. The structures were solved by the dual-space algorithm using SHELXT Version 2014/5 [47] or SHELXS Version 2013/1 [48], and refined by the full-matrix least-squares method on $F^{2}$ using SHELXL Version 2014/7 [48]. All calculations were performed using the CrystalStructure software package [49]. Most non-hydrogen atoms were refined anisotropically, and the hydrogen atoms of organic moieties were refined using the riding model. Further details of the crystal structure investigation may be obtained free of charge from the Cambridge Crystallographic Data Centre, 12 Union Road, Cambridge CB2 1EZ, UK; fax: (+44) 1223336 033; or E-Mail: deposit@ccdc.cam.ac.uk (CCDC 1934917-1934920).

\section{Results}

\subsection{Mo $\mathrm{M}_{8}$ hybrids with Polymerizable Ionic Liquids}

Octamolybdate $\left(\mathrm{Mo}_{8}\right)$ hybrids with the polymerizable ionic liquids of MAIm and MAImC 8 were obtained as colorless precipitates in ca. 50\% yield. IR spectra of both as-prepared MAIm-Mo $(\mathbf{1}$, Figure 2a) and $\mathrm{MAImC}_{8}-\mathrm{Mo}_{8}$ (2, Figure 2c) exhibited characteristic peaks of the $\beta-\mathrm{Mo}_{8}$ anion [50-52]

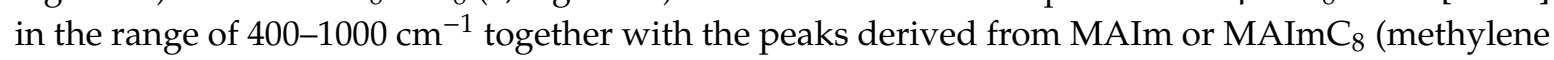
groups in $2800-3000 \mathrm{~cm}^{-1}$ and methacryloyl group in $1200-1800 \mathrm{~cm}^{-1}$ ), indicating the successful hybridization of $\mathrm{Mo}_{8}$ with the polymerizable ionic liquids.

Both as-prepared precipitates of $\mathbf{1}$ and $\mathbf{2}$ were successfully recrystallized by using acetonitrile/ethanol solution to obtain single crystals. The IR spectra of recrystallized $\mathbf{1}$ (Figure $2 \mathrm{~b}$ ) were almost identical to that of the as-prepared $\mathbf{1}$ (Figure 2a), indicating that the molecular structures were retained before and after the recrystallization. The molecular structures of $\mathbf{2}$ were also the same before and after the recrystallization as observed in the IR spectra of hybrid crystal 2 (Figure 2c,d).

$\mathrm{X}$-ray structure analyses together with $\mathrm{CHN}$ elemental analyses revealed that the $\mathrm{Mo}_{8}$ hybrid crystals were formulated to be $\left[\left\{\mathrm{CH}_{2}=\mathrm{C}\left(\mathrm{CH}_{3}\right) \mathrm{COO}\left(\mathrm{CH}_{2}\right)_{2}\right\} \mathrm{C}_{3} \mathrm{H}_{4} \mathrm{~N}_{2}\right]_{3} \mathrm{Na}\left[\mathrm{Mo}_{8} \mathrm{O}_{26}\right]$ for $\mathbf{1}$ and $\left[\left\{\mathrm{CH}_{2}=\mathrm{C}\left(\mathrm{CH}_{3}\right) \mathrm{COO}\left(\mathrm{CH}_{2}\right)_{2}\right\} \mathrm{C}_{3} \mathrm{H}_{3} \mathrm{~N}_{2}\left(\mathrm{C}_{8} \mathrm{H}_{17}\right)\right]_{3} \mathrm{Na}\left[\mathrm{Mo}_{8} \mathrm{O}_{26}\right]$ for 2, respectively (Table 1, Figure 3). Both hybrid crystals contained three MAIm (1+ charge) or $\mathrm{MAImC}_{8}\left(1+\right.$ charge) and one $\mathrm{Na}^{+}$associated with one $\beta$-type $\mathrm{Mo}_{8}$ anion (4- charge), being similar to other hybrid crystals consisting of $\beta$-type Mo 8 anions $[42,53,54]$. Both crystal structures contained a one-dimensional (1D) infinite chain composed of the $\mathrm{Na}^{+}$cation and $\mathrm{Mo}_{8}$ anion $\left(\mathrm{Mo}_{8}-\mathrm{Na}^{+} 1 \mathrm{D}\right.$ chain) as shown in Figure $3 a, b$, while the coordination environments of $\mathrm{Na}^{+}$were different. The $\mathrm{Na}^{+}$cation in $\mathbf{1}$ was surrounded by $\mathrm{O}$ atoms of two $\mathrm{Mo}_{8}$ 
anions and two MAIm cations, and located in a six-fold coordination environment (Na-O distance: 2.28-2.43 $\AA$, mean value: $2.36 \AA$ ) to form a zig-zag chain structure (Figure 3a, right). On the other hand, the $\mathrm{Na}^{+}$cation in 2 was sandwiched by only two $\beta-\mathrm{Mo}_{8}$ anions to possess an eight-fold coordination environment (Na-O distance: $2.40-2.90 \AA$, mean value: $2.60 \AA$ ), resulting in a more straight chain structure (Figure 3b, right).

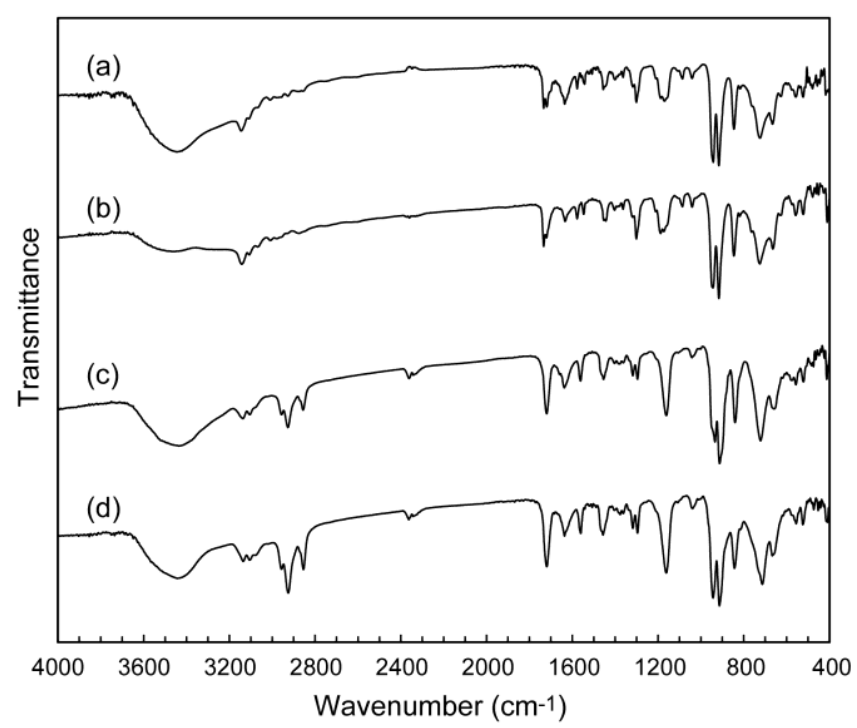

Figure 2. IR spectra of $\mathrm{Mo}_{8}$ hybrid crystals: (a) as-prepared 1; (b) recrystallized 1; (c) as-prepared 2; (d) recrystallized 2.

Table 1. Crystallographic data of the hybrid crystals.

\begin{tabular}{|c|c|c|c|c|}
\hline Compound & 1 & 2 & 3 & 4 \\
\hline Chemical formula & $\mathrm{C}_{27} \mathrm{H}_{39} \mathrm{~N}_{6} \mathrm{NaMo}_{8} \mathrm{O}_{32}$ & $\mathrm{C}_{51} \mathrm{H}_{87} \mathrm{~N}_{6} \mathrm{NaMo}_{8} \mathrm{O}_{33}$ & $\mathrm{C}_{40} \mathrm{H}_{60} \mathrm{~N}_{8} \mathrm{SiW}_{12} \mathrm{O}_{50}$ & $\mathrm{C}_{72} \mathrm{H}_{107} \mathrm{~N}_{8} \mathrm{SiW}_{12} \mathrm{O}_{51}$ \\
\hline Formula weight & 1750.14 & 2102.78 & 3687.22 & 4134.95 \\
\hline Crystal system & monoclinic & orthorhombic & monoclinic & monoclinic \\
\hline Space group & $I 2 / a($ No. 15$)$ & $P 2{ }_{1}{ }_{1} 2_{1}$ (No. 19) & $P 2_{1} / n$ (No. 14$)$ & $P 2_{1} / c$ (No. 14$)$ \\
\hline$a(\AA)$ & $13.6080(3)$ & $9.33330(10)$ & $14.8460(3)$ & $20.7451(16)$ \\
\hline$b(\AA)$ & $17.6620(4)$ & $18.6205(2)$ & $12.6020(3)$ & $21.2737(6)$ \\
\hline$c(\AA)$ & $21.8453(5)$ & $42.7175(5)$ & $19.6940(5)$ & $25.5199(8)$ \\
\hline$\alpha\left(^{\circ}\right)$ & 90.0000 & 90.0000 & 90.0000 & 90.0000 \\
\hline$\beta\left(^{\circ}\right)$ & $95.0422(14)$ & 90.0000 & $98.6520(10)$ & $103.067(5)$ \\
\hline$\gamma\left({ }^{\circ}\right)$ & 90.0000 & 90.0000 & 90.0000 & 90.0000 \\
\hline$V\left(\AA^{3}\right)$ & $5230.1(2)$ & $7423.90(14)$ & $3642.61(15)$ & $10970.9(10)$ \\
\hline Z & 4 & 4 & 2 & 4 \\
\hline$\rho_{\text {calcd }}\left(\mathrm{g} \mathrm{cm}^{-3}\right)$ & 2.222 & 1.881 & 3.361 & 2.503 \\
\hline$T(\mathrm{~K})$ & 100 & 100 & 100 & 100 \\
\hline Wavelength (̊) & 0.80000 & 0.63000 & 0.60000 & 0.71075 \\
\hline$\mu\left(\mathrm{mm}^{-1}\right)$ & 2.725 & 0.976 & 12.044 & 12.638 \\
\hline $\begin{array}{c}\text { No. of reflections } \\
\text { measured }\end{array}$ & 35127 & 102284 & 94446 & 106869 \\
\hline $\begin{array}{l}\text { No. of independent } \\
\text { reflections }\end{array}$ & 5143 & 15761 & 14513 & 24752 \\
\hline$R_{\text {int }}$ & 0.0600 & 0.0800 & 0.0870 & 0.1418 \\
\hline No. of parameters & 394 & 883 & 507 & 644 \\
\hline$R_{1}(I>2 \sigma(I))$ & 0.0553 & 0.0564 & 0.0721 & 0.0777 \\
\hline$w R_{2}$ (all data) & 0.1680 & 0.1576 & 0.2046 & 0.2256 \\
\hline
\end{tabular}


(a)

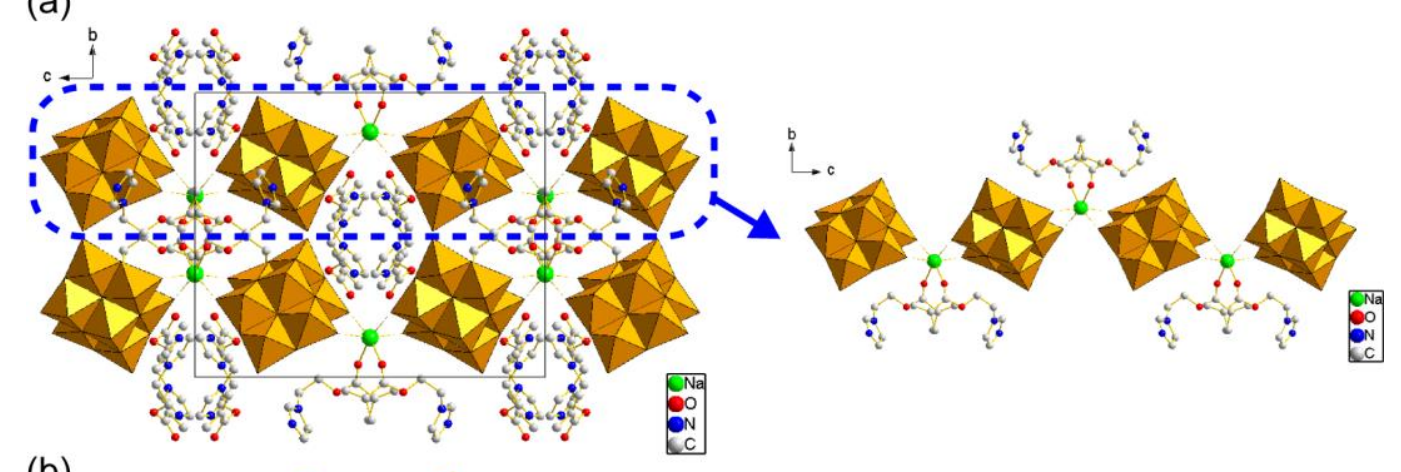

(b)

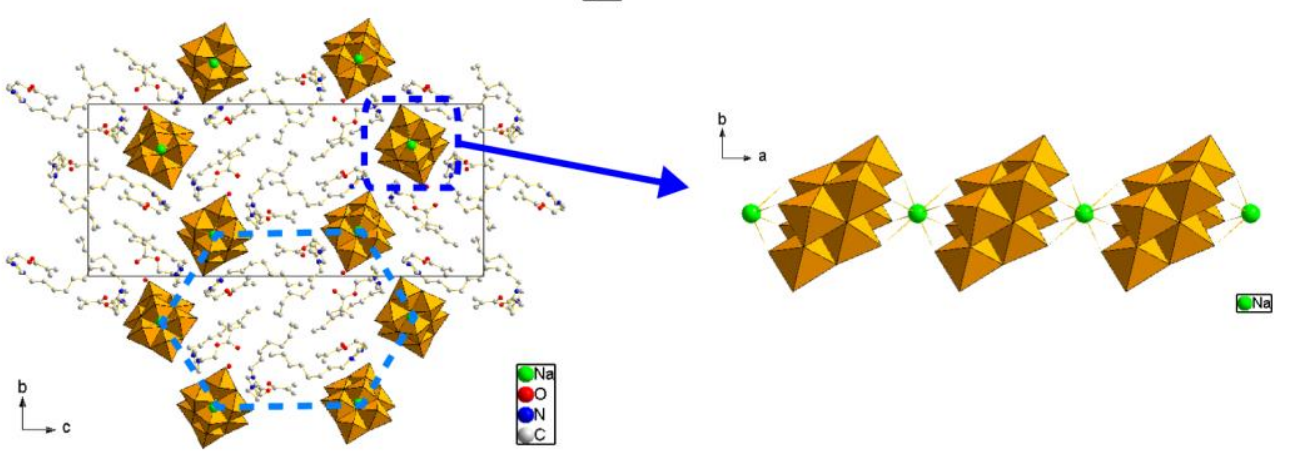

(c)
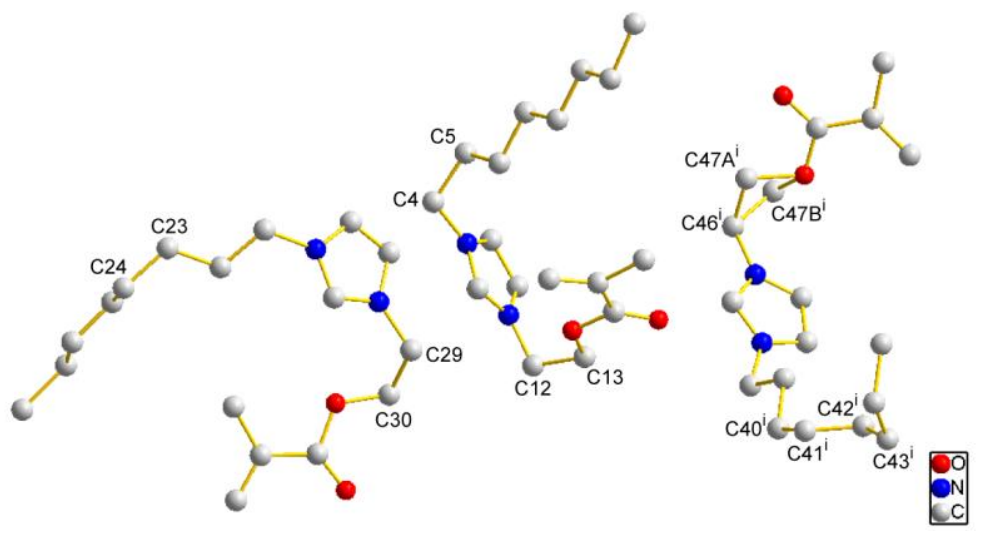

Figure 3. Crystal structures of $\mathrm{Mo}_{8}$ hybrid crystals (Na: green, $\mathrm{C}$ : gray, $\mathrm{N}$ : blue, $\mathrm{O}$ : red). $\mathrm{Mo}_{8}$ anions are represented by polyhedrons. $\mathrm{H}$ atoms are omitted for clarity; (a) packing diagram of $\mathbf{1}$ (left, along $a$ axis) and molecular arrangement of the $\mathrm{Mo}_{8}-\mathrm{Na}^{+} 1 \mathrm{D}$ chain in $\mathbf{1}$ (right, along $a$ axis); (b) packing diagram of 2 (left, along $a$ axis) and molecular arrangement of $\mathrm{Mo}_{8}-\mathrm{Na}^{+} 1 \mathrm{D}$ chains in 2 (right, along $c$ axis). A honeycomb-like arrangement of $\mathrm{Mo}_{8}-\mathrm{Na}^{+} 1 \mathrm{D}$ chains is highlighted by a light-blue broken hexagon; (c) molecular conformations of crystallographically independent $\mathrm{MAImC}_{8}$ cations in 2. C atoms relevant to the gauche conformation are numbered. Symmetry code: (i) $1-x,-0.5+y, 0.5-z$.

In addition, the packing manners of the $\mathrm{Mo}_{8}-\mathrm{Na}^{+} 1 \mathrm{D}$ chains in the crystal structures of $\mathbf{1}$ and $\mathbf{2}$ were different. The $\mathrm{Mo}_{8}-\mathrm{Na}^{+} 1 \mathrm{D}$ chains in $\mathbf{1}$ were rather densely packed in the crystal structure (Figure 3a, left), while the $\mathrm{Mo}_{8}-\mathrm{Na}^{+} 1 \mathrm{D}$ chains in 2 were located more separately, to exhibit a honeycomb-like structure along the $a$-axis direction (Figure $3 \mathrm{~b}$, left). Namely, $\mathbf{1}$ had a rather isotropic arrangement of the $\mathrm{Mo}_{8}-\mathrm{Na}^{+} 1 \mathrm{D}$ chains, while 2 possessed a more anisotropic arrangement of the $\mathrm{Mo}_{8}-\mathrm{Na}^{+} 1 \mathrm{D}$ chains in the bulk crystal structure. This difference in the arrangements of the $\mathrm{Mo}_{8}-\mathrm{Na}^{+} 1 \mathrm{D}$ chains between $\mathbf{1}$ and $\mathbf{2}$ will be due to the presence of the amphiphilic moiety in the polymerizable ionic liquid cations. The $\mathrm{MAImC}_{8}$ had a long alkyl chain, which interacted with itself to control the arrangement of the $\mathrm{Mo}_{8}-\mathrm{Na}^{+} 1 \mathrm{D}$ chain in the crystal structures of 2 [30-32]. As shown in Figure 3c, several C-C bonds in the methylene groups of $\mathrm{MAImC}_{8}$ had a gauche conformation, which forced both octyl and methacryloyl groups to locate to the same side against the charged and hydrophilic imidazolium ring. 
These molecular conformations of $\mathrm{MAImC}_{8}$ caused the segregation of hydrophilic and hydrophobic parts in the crystal structure of $\mathbf{2}$, resulting in the anisotropic honeycomb-like arrangement of the $\mathrm{Mo}_{8}-\mathrm{Na}^{+} 1 \mathrm{D}$ chains (Figure $3 \mathrm{~b}$, left). The octyl chains were not interdigitated in a straight manner.

Powder XRD patterns of as-prepared $\mathbf{1}$ and $\mathbf{2}$ (Figure $4 \mathrm{a}, \mathrm{c}$ ) were quite similar in the peak positions to the patterns calculated from the single crystal structure of $\mathbf{1}$ and $\mathbf{2}$ (Figure $4 \mathrm{~b}, \mathrm{~d}$ ), indicating that the crystal structures of $\mathbf{1}$ and $\mathbf{2}$ were retained before and after the recrystallization. Slight differences in the peak intensity and position of the patterns may be derived from the difference in the measurement temperature (powder: ambient temperature, single crystal: $100 \mathrm{~K}$ ). This suggests that the $\mathrm{Mo}_{8}-\mathrm{Na}^{+} 1 \mathrm{D}$ chains were already formed in the as-prepared precipitates due to their stable and rigid structures. The amphiphilic moiety of $\mathrm{MAImC}_{8}$ in $\mathbf{2}$ also contributed to the formation of a stable and rigid crystal structure derived from the van der Waals interactions between the octyl chains.

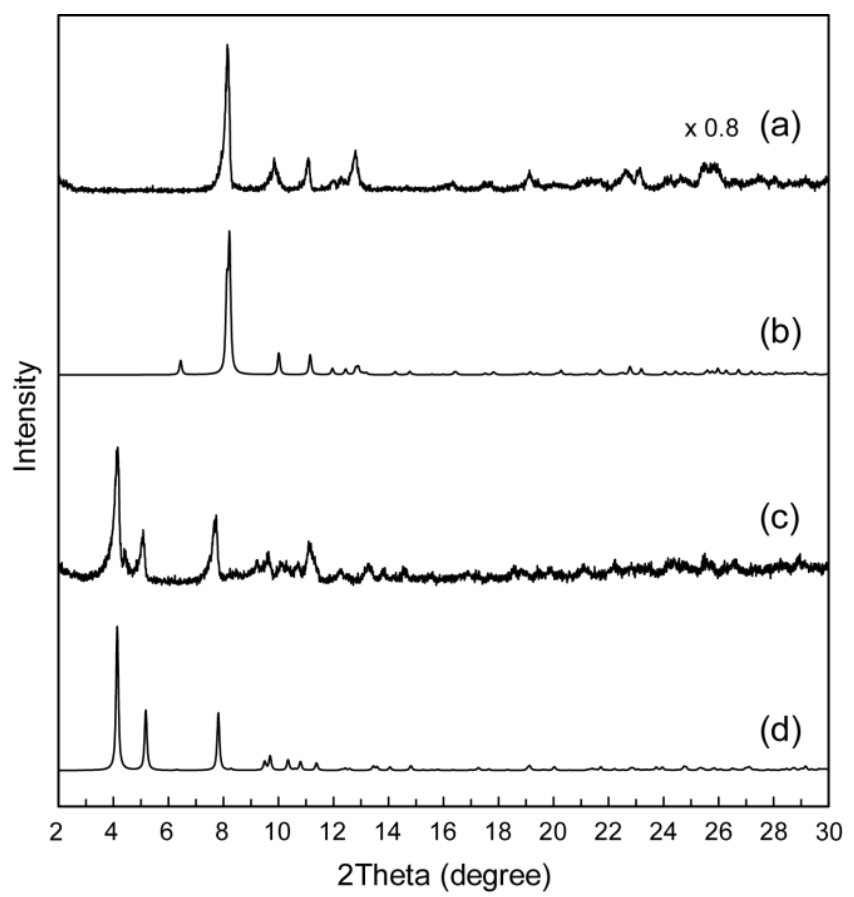

Figure 4. Powder XRD patterns of $\mathrm{Mo}_{8}$ hybrid crystals: (a) as-prepared $\mathbf{1}$; (b) calculated pattern of $\mathbf{1}$ using the structure obtained by single-crystal X-ray diffraction; (c) as-prepared 2; (d) calculated pattern of 2 using the structure obtained by single-crystal X-ray diffraction.

\section{2. $\mathrm{SiW}_{12}$ Hybrids with Polymerizable Ionic Liquids}

Dodecatungstosilicate $\left(\mathrm{SiW}_{12}\right)$ hybrids with the polymerizable ionic liquids were obtained as colorless precipitates in ca. $50 \%$ yield for MAIm-SiW $\mathrm{M}_{12}$ (3) and ca. $70 \%$ yield for $\mathrm{MAImC}_{8}-\mathrm{SiW}_{12}$ (4), respectively. The characteristic peaks of $\mathrm{SiW}_{12}[17,44,55]$ were observed for as-prepared 3 (Figure 5a) and 4 (Figure 5c) in the range of $400-1100 \mathrm{~cm}^{-1}$ of IR spectra. The presence of the polymerizable ionic liquids were confirmed by the IR spectra (in the range of $2800-3000 \mathrm{~cm}^{-1}$ for methylene groups and $1200-1800 \mathrm{~cm}^{-1}$ for methacryloyl group), which showed successful formation of the hybrid crystals comprising $\mathrm{SiW}_{12}$ and the polymerizable ionic liquids. 


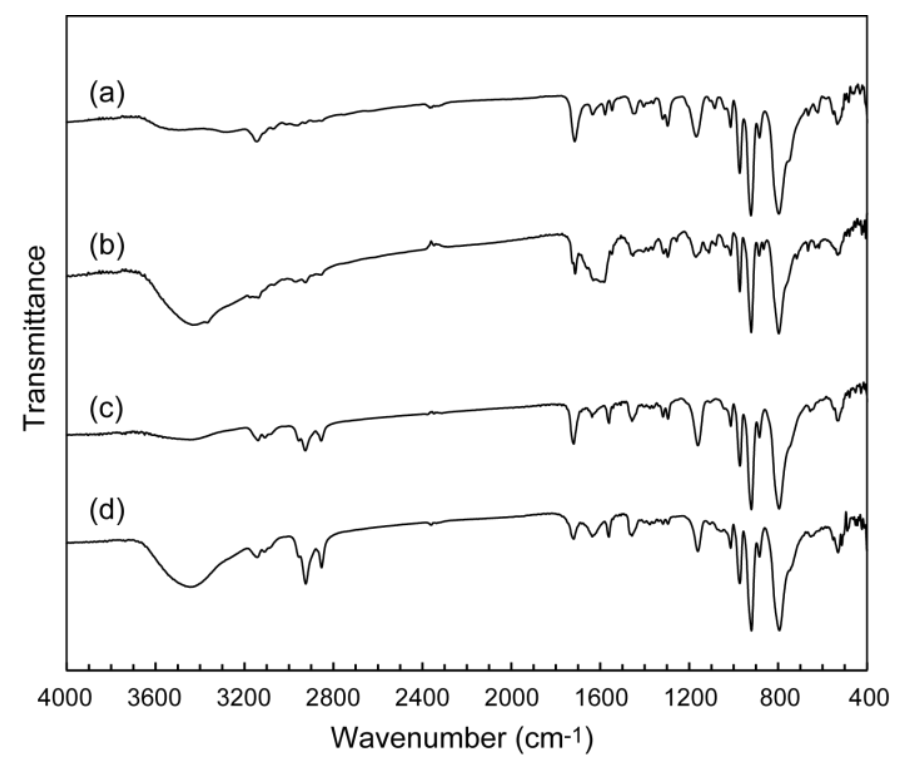

Figure 5. IR spectra of $\mathrm{Mo}_{8}$ hybrid crystals: (a) as-prepared 3; (b) recrystallized 3; (c) as-prepared 4; (d) recrystallized 4.

Single crystals of 3 were obtained from 1,4-dioxane $\left(\mathrm{C}_{4} \mathrm{H}_{4} \mathrm{O}_{2}\right)$ solution, while single crystals of 4 were grown from 1,4-dioxane/ethanol solution. As-prepared 3 (Figure 5a) and recrystallized 3 (Figure $5 b$ ) were almost the same in the IR spectra, indicating the retention of the molecular structures before and after the recrystallization. A slight difference in the peaks in the range of $1500-1700 \mathrm{~cm}^{-1}$ may be derived from the difference in the crystal structures of as-prepared $\mathbf{3}$ and recrystallized $\mathbf{3}$ (see below). The retention of the molecular structures of 4 was also verified by the IR spectra measured before and after the recrystallization (Figure $5 \mathrm{c}, \mathrm{d}$ ).

Chemical formulae were revealed to be $\left[\left\{\mathrm{CH}_{2}=\mathrm{C}\left(\mathrm{CH}_{3}\right) \mathrm{COO}\left(\mathrm{CH}_{2}\right)_{2}\right\} \mathrm{C}_{3} \mathrm{H}_{4} \mathrm{~N}_{2}\right]_{4}\left[\mathrm{SiW}_{12} \mathrm{O}_{40}\right] \cdot \mathrm{C}_{4} \mathrm{H}_{4} \mathrm{O}_{2}$ for 3 and $\left[\left\{\mathrm{CH}_{2}=\mathrm{C}\left(\mathrm{CH}_{3}\right) \mathrm{COO}\left(\mathrm{CH}_{2}\right)_{2}\right\} \mathrm{C}_{3} \mathrm{H}_{3} \mathrm{~N}_{2}\left(\mathrm{C}_{8} \mathrm{H}_{17}\right)\right]_{4}\left[\mathrm{SiW}_{12} \mathrm{O}_{40}\right] \cdot \mathrm{C}_{4} \mathrm{H}_{4} \mathrm{O}_{2} \cdot \mathrm{H}_{2} \mathrm{O}$ for 4, respectively (Table 1). These hybrid crystals contained four polymerizable ionic liquid cations (1+ charge) associated with one $\mathrm{SiW}_{12}$ anion (4- charge). All of the protons of the starting $\mathrm{H}-\mathrm{SiW}_{12}$ were replaced by ion-exchange reactions without remaining counter cations after the hybridization [44,56-58], which was different from the cases of $\mathrm{Mo}_{8}$ hybrid crystals of $\mathbf{1}$ and $\mathbf{2}$. Both recrystallized $\mathrm{SiW}_{12}$ hybrid crystals of 3 and 4 contained the solvents of crystallization (1,4-dioxane utilized in the recrystallization process for 3; 1,4-dioxane and water for 4), which also contrasts with the Mo 8 hybrid crystals of 1 and 2. Figure 6 depicts crystal structures of 3 (Figure 6a) and 4 (Figure 6b). In both crystals, each $\mathrm{SiW}_{12}$ anion was isolated by the imidazolium moieties of the polymerizable ionic liquids (Figure 6a, right for 3; Figure $6 \mathrm{~b}$, right for 4). 
(a)
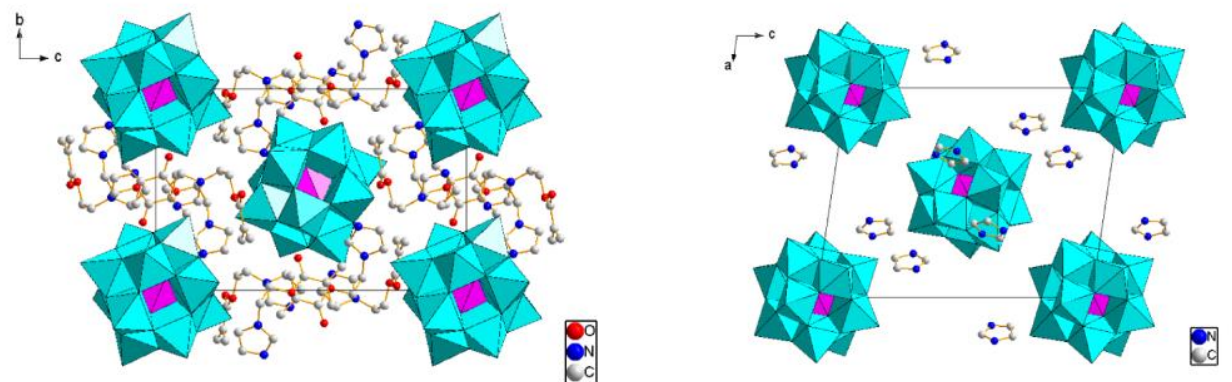

(b)

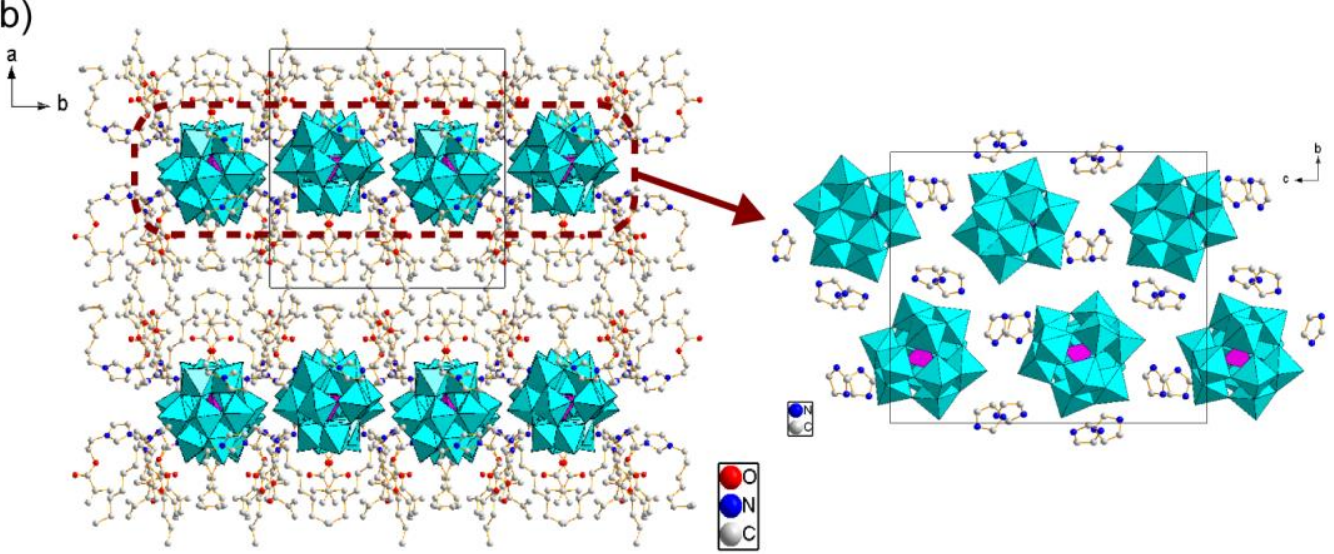

Figure 6. Crystal structures of $\mathrm{SiW}_{12}$ hybrid crystals (C: gray, $\mathrm{N}$ : blue, O: red). $\mathrm{SiW}_{12}$ anions are represented by polyhedrons. $\mathrm{H}$ atoms are omitted for clarity; (a) packing diagram of 3 (left, along $a$ axis) and molecular arrangement of $\mathrm{SiW}_{12}$ anions in 3 (right, along $b$ axis); (b) packing diagram of 4 (left, along $c$ axis) and molecular arrangement of $\mathrm{SiW}_{12}$ anions in 4 (right, along $a$ axis).

The molecular arrangements of the $\mathrm{SiW}_{12}$ anions in the bulk crystal structures of 3 and 4 were quite different. The $\mathrm{SiW}_{12}$ anions are arranged rather densely and isotropically in 3 (Figure 6a, left). On the contrary, the $\mathrm{SiW}_{12}$ anions in 4 formed the inorganic monolayers sandwiched by the $\mathrm{MAImC}_{8}$ organic layers with an interlayer distance of $20.2 \AA$ (Figure $6 \mathrm{~b}$, left), and exhibited much more anisotropic structure than 3 . Such anisotropic molecular arrangement will be induced by the amphiphilic moiety of the $\mathrm{MAImC}_{8}$ cations. The MAImC 8 in 4 had similar conformations to those observed in 2 (Figure 3c). The octyl chains in 4 were not interdigitated in a straight manner as in the crystals of 2.

The powder XRD pattern of as-prepared 3 (Figure 7a) was different from that calculated from the single crystal structure of $\mathbf{3}$ (Figure $7 \mathrm{~b}$ ). This demonstrates that the crystal structures of $\mathbf{3}$ changed after the recrystallization, probably because of desolvation of solvent molecules of the crystals under the ambient atmosphere. On the other hand, powder XRD patterns of as-prepared 4 (Figure 7c) were essentially similar to the patterns calculated from the single crystal structure of 4 (Figure 7d), indicating that the crystal structures of 4 were retained before and after the recrystallization. These results suggest that the amphiphilic moiety of the polymerizable ionic liquid enabled formation of the stable crystal structures of 4 owing to the van der Waals interactions between the octyl chains. 


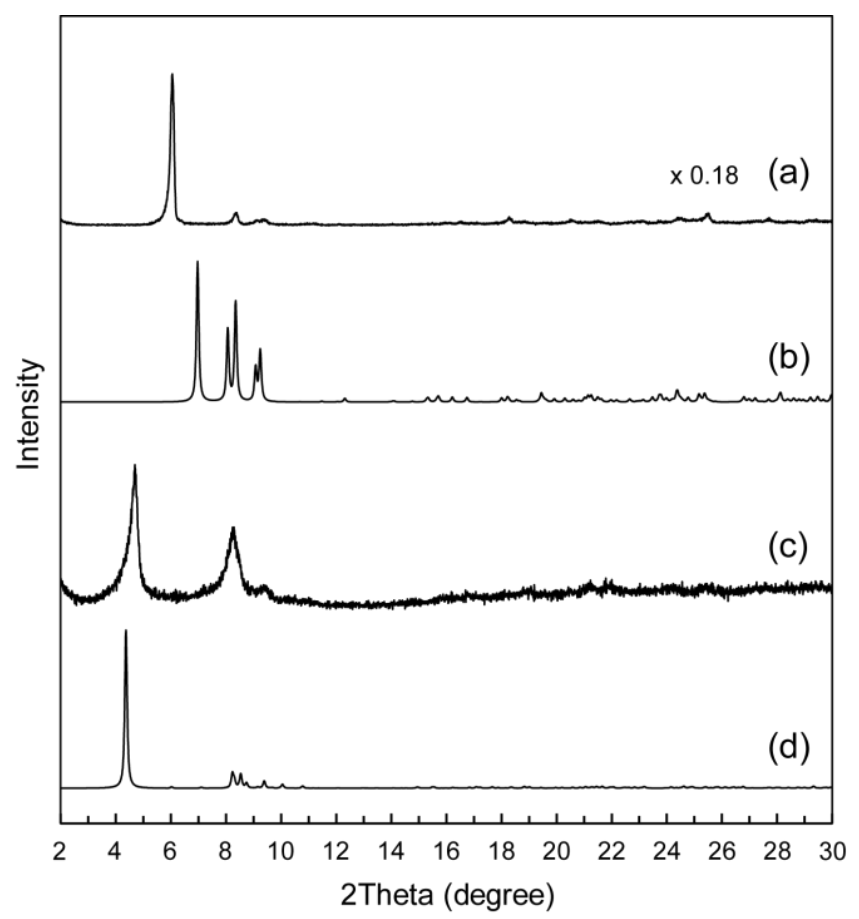

Figure 7. Powder XRD patterns of $\mathrm{SiW}_{12}$ hybrid crystals: (a) as-prepared 3; (b) calculated pattern of 3 using the structure obtained by single-crystal X-ray diffraction; (c) as-prepared 4; (d) calculated pattern of 4 using the structure obtained by single-crystal X-ray diffraction.

\section{Discussion}

As observed in the crystal structures of $\mathbf{2}$ and $\mathbf{4}$, introducing the amphiphilic moiety into the polymerizable ionic liquid enabled the construction of the anisotropic molecular arrangements of POM inorganic clusters in the bulk crystal structures. The amphiphilic MAImC $\mathrm{C}_{8}$ cation behaved as a structure-directing reagent, like typical surfactants [30-32], owing to the van der Waals interactions between the octyl chains of MAImC ${ }_{8}$. The presence of a long alkyl chain in the polymerized ionic liquids induced the segregation of hydrophilic parts (charged POM and imidazolium ring) and a hydrophobic moiety (alkyl chain and methacryloyl group), which led to the formation of the anisotropic POM arrangements in the crystal structures of $\mathbf{2}$ and 4 . Introducing the amphiphilic moiety into the polymerizable ionic liquid also realized stable crystal structures. The crystal structures of 2 and 4 were retained before and after the recrystallization process, although the crystal structures of the hybrid crystal of 3 without the amphiphilic moiety changed in their crystal structures through the recrystallizations procedures.

The $\beta$-type $\mathrm{Mo}_{8}$ anion tends to coordinate metal cations to form a 1D chain or two-dimensional (2D) layered structures [42,54]. The smaller metal cations such as $\mathrm{Na}^{+} \mathrm{or} \mathrm{Ag}^{+}$preferred the 1D chain structure, while the larger cations such as $\mathrm{K}^{+}$or $\mathrm{Cs}^{+}$gave rise to a 2D layered structure. In the case of 1 and 2, the $\mathrm{Na}^{+}$cation of the starting material $\left(\mathrm{Na}_{2} \mathrm{MoO}_{4} \cdot 2 \mathrm{H}_{2} \mathrm{O}\right)$ remained to form the $\mathrm{Mo}_{8}-\mathrm{Na}^{+}$ $1 \mathrm{D}$ chain structures in the crystal structures. Furthermore, $\mathbf{1}$ and $\mathbf{2}$ kept their molecular and crystal structures before and after the recrystallization (Figures 2 and 4), suggesting the retention of the $\mathrm{Mo}_{8}-\mathrm{Na}^{+} 1 \mathrm{D}$ chain structures. These stable $\mathrm{Mo}_{8}-\mathrm{Na}^{+}$1D chain structures could be beneficial to the $\mathrm{Na}^{+}$-conducting materials. On the other hand, the typical Keggin-type $\mathrm{SiW}_{12}$ anion exhibits $T_{d}$ symmetry, which is higher than the $C_{2 h}$ symmetry of the $\beta-M_{8}$ anion (Figure $\left.1 b\right)[59,60]$. The more spherical $\mathrm{SiW}_{12}$ anion tends to be surrounded by the heterocyclic moiety of the polymerizable ionic liquid or surfactant $[44,56]$, resulting in the isolated arrangement of $\mathrm{SiW}_{12}$ without the coordination by metal cations. 
As described here, introducing the amphiphilic moiety into the polymerizable ionic liquid is an effective way to control the POM arrangements in the hybrid single crystals. Such controlled arrangement of POM anions will have beneficial emergent functions such as conductive properties [12,13,29]. In principle, these POM hybrid crystals of $\mathbf{1}-\mathbf{4}$ behave as inorganic-organic hybrid monomers to construct hybrid polymers [20,42-44], which could pave the way to another category of conductive materials. The polymerization of these hybrids and investigation of conductivities are in progress.

\section{Patents}

A Japanese patent (JP 2018012758 A) resulted from the work reported in this manuscript (T.I., Y.N., S.K., M.H., Y.O.).

Supplementary Materials: The following are available online at http://www.mdpi.com/1996-1944/12/14/2283/s1, synthetic procedures of polymerizable ionic liquids, Figure S1: Synthetic route of MAIm, cif files of 1-4.

Author Contributions: Conceptualization, T.I. and Y.N.; methodology, T.I., Y.N., S.K., M.H., Y.O.; formal analysis, T.M., M.W., S.O., T.I.; investigation, T.M., J.K., Y.K., M.W., S.O.; resources, S.K.; writing—original draft preparation, T.I.; visualization, T.M., T.I.; funding acquisition, T.I.

Funding: This research was funded in part by JSPS KAKENHI (grant No. JP26410245), Research and Study Project of Tokai University Educational System General Research Organization (grant No. PJ2014-02), and JSPS Core-to-Core Program. The APC was funded by Iketani Science and Technology Foundation (grant No. 0311048-A).

Acknowledgments: X-ray diffraction measurements with synchrotron radiation were performed at the Pohang Accelerator Laboratory (Beamline 2D), a synchrotron radiation facility in Pohang, Republic of Korea, supported by Pohang University of Science and Technology (POSTECH).

Conflicts of Interest: The authors declare no conflict of interest. The funders had no role in the design of the study; in the collection, analyses, or interpretation of data; in the writing of the manuscript, or in the decision to publish the results.

\section{References}

1. Armand, M.; Endres, F.; MacFarlane, D.R.; Ohno, H.; Scrosati, B. Ionic liquid materials for the electrochemical challenges of the future. Nat. Mater. 2009, 8, 621-629. [CrossRef] [PubMed]

2. Kato, T.; Uchida, J.; Ichikawa, T.; Sakamoto, T. Functional liquid crystals towards the next generation of materials. Angew. Chem. Int. Ed. 2018, 57, 4355-4371. [CrossRef] [PubMed]

3. Welton, T. Room-temperature ionic liquids. Solvents for synthesis and catalysis. Chem. Rev. 1999, 99, 2071-2083. [CrossRef] [PubMed]

4. Wasserscheid, P.; Keim, W. Ionic liquids-new "solutions" for transition metal catalysis. Angew. Chem. Int. Ed. 2000, 39, 3772-3789. [CrossRef]

5. Mudring, A.-V.; Tang, S. Ionic liquids for lanthanide and actinide chemistry. Eur. J. Inorg. Chem. 2010, 2010, 2569-2581. [CrossRef]

6. Nishimura, N.; Ohno, H. 15th anniversary of polymerised ionic liquids. Polymer 2014, 55, 3289-3297. [CrossRef]

7. Watanabe, M.; Thomas, M.L.; Zhang, S.; Ueno, K.; Yasuda, T.; Dokko, K. Application of ionic liquids to energy storage and conversion materials and devices. Chem. Rev. 2017, 117, 7190-7239. [CrossRef]

8. Çelik, S.Ü.; Bozkurt, A.; Hosseini, S.S. Alternatives toward proton conductive anhydrous membranes for fuel cells: Heterocyclic protogenic solvents comprising polymer electrolytes. Prog. Polym. Sci. 2012, 37, 1265-1291. [CrossRef]

9. Kato, T.; Mizoshita, N.; Kishimoto, K. Functional liquid-crystalline assemblies: Self-organized soft materials. Angew. Chem. Int. Ed. 2006, 45, 38-68. [CrossRef]

10. Qian, W.; Texter, J.; Yan, F. Frontiers in poly(ionic liquid)s: Syntheses and applications. Chem. Soc. Rev. 2017, 46, 1124-1159. [CrossRef]

11. Nagase, Y.; Suleimenova, B.; Umeda, C.; Taira, K.; Oda, T.; Suzuki, S.; Okamura, Y.; Koguchi, S. Syntheses of aromatic polymers containing imidazolium moiety and the surface modification of a highly gas permeable membrane using the nanosheets. Polymer 2018, 135, 142-153. [CrossRef] 
12. Coronado, E.; Gómez-García, C.J. Polyoxometalate-based molecular materials. Chem. Rev. 1998, 98, $273-296$. [CrossRef] [PubMed]

13. Coronado, E.; Giménez-Saiz, C.; Gómez-García, C.J. Recent advances in polyoxometalate-containing molecular conductors. Coord. Chem. Rev. 2005, 249, 1776-1796. [CrossRef]

14. Long, D.-L.; Burkholder, E.; Cronin, L. Polyoxometalate clusters, nanostructures and materials: From self assembly to designer materials and devices. Chem. Soc. Rev. 2007, 36, 105-121. [CrossRef] [PubMed]

15. Nyman, M. Polyoxoniobate chemistry in the 21st century. Dalton Trans. 2011, 40, 8049-8058. [CrossRef]

16. Proust, A.; Matt, B.; Villanneau, R.; Guillemot, G.; Gouzerh, P.; Izzet, G. Functionalization and post-functionalization: A step towards polyoxometalate-based materials. Chem. Soc. Rev. 2012, 41, 7605-7622. [CrossRef] [PubMed]

17. Okuhara, T.; Mizuno, N.; Misono, M. Catalytic chemistry of heteropoly compounds. Adv. Catal. 1996, 41, 113-252.

18. Yamase, T. Photo- and electrochromism of polyoxometalates and related materials. Chem. Rev. 1998, 98, 307-325. [CrossRef] [PubMed]

19. Sadakane, M.; Steckhan, E. Electrochemical properties of polyoxometalates as electrocatalysts. Chem. Rev. 1998, 98, 219-237. [CrossRef] [PubMed]

20. Qi, W.; Wu, L. Polyoxometalate/polymer hybrid materials: Fabrication and properties. Polym. Int. 2009, 58, 1217-1225. [CrossRef]

21. Honma, I.; Yamada, M. Bio-inspired membranes for advanced polymer electrolyte fuel cells. Anhydrous proton-conducting membrane via molecular self-assembly. Bull. Chem. Soc. Jpn. 2007, 80, 2110-2123. [CrossRef]

22. Oh, S.-Y.; Yoshida, T.; Kawamura, G.; Muto, H.; Sakai, M.; Matsuda, A. Inorganic-organic composite electrolytes consisting of polybenzimidazole and Cs-substituted heteropoly acids and their application for medium temperature fuel cells. J. Mater. Chem. 2010, 20, 6359-6366. [CrossRef]

23. Wu, X.; Tong, X.; Wu, Q.; Ding, H.; Yan, W. Reversible phase transformation-type electrolyte based on layered shape polyoxometalate. J. Mater. Chem. A 2014, 2, 5780-5784. [CrossRef]

24. Bourlinos, A.B.; Raman, K.; Herrera, R.; Zhang, Q.; Archer, L.A.; Giannelis, E.P. A liquid derivative of 12-tungstophosphoric acid with unusually high conductivity. J. Am. Chem. Soc. 2004, 126, 15358-15359. [CrossRef]

25. Leng, Y.; Wang, J.; Zhu, D.; Ren, X.; Ge, H.; Shen, L. Heteropolyanion-based ionic liquids: Reaction-induced self-separation catalysts for esterification. Angew. Chem. Int. Ed. 2009, 48, 168-171. [CrossRef] [PubMed]

26. Rafiee, E.; Eavani, S. Polyoxometalate-based acid salts with tunable separation properties as recyclable Brönsted acid catalysts for the synthesis of $\beta$-keto enol ethers. Catal. Commun. 2012, 25, 64-68. [CrossRef]

27. Chen, X.; Souvanhthong, B.; Wang, H.; Zheng, H.; Wang, X.; Huo, M. Polyoxometalate-based ionic liquid as thermoregulated and environmentally friendly catalyst for starch oxidation. Appl. Catal. B 2013, 138-139, 161-166. [CrossRef]

28. Rickert, P.G.; Antonio, M.R.; Firestone, M.A.; Kubatko, K.-A.; Szreder, T.; James, F.; Wishart, J.F.; Dietz, M.L. Tetraalkylphosphonium polyoxometalate ionic liquids: Novel, organic-inorganic hybrid materials. J. Phys. Chem. B 2007, 111, 4685-4692. [CrossRef]

29. Kanatzidis, M.G. Discovery-Synthesis, Design, and prediction of chalcogenide phases. Inorg. Chem. 2017, 56, 3158-3173. [CrossRef]

30. Huo, Q.; Margolese, D.I.; Ciesla, U.; Demuth, D.G.; Feng, P.; Gier, T.E.; Sieger, P.; Firouzi, A.; Chmelka, B.F.; Schüth, F.; et al. Organization of organic molecules with inorganic molecular species into nanocomposite biphase arrays. Chem. Mater. 1994, 6, 1176-1191. [CrossRef]

31. Kanatzidis, M.G. Beyond silica: Nonoxidic mesostructured materials. Adv. Mater. 2007, 19, $1165-1181$. [CrossRef]

32. Yamauchi, Y.; Kuroda, K. Rational design of mesoporous metals and related nanomaterials by a soft-template approach. Chem. Asian J. 2008, 3, 664-676. [CrossRef] [PubMed]

33. Song, Y.-F.; Long, D.-L.; Ritchie, C.; Cronin, L. Nanoscale polyoxometalate-based inorganic/organic hybrids. Chem. Rec. 2011, 11, 158-171. [CrossRef] [PubMed]

34. Yin, P.; Li, D.; Liu, T. Solution behaviors and self-assembly of polyoxometalates as models of macroions and amphiphilic polyoxometalate-organic hybrids as novel surfactants. Chem. Soc. Rev. 2012, 41, 7368-7383. [CrossRef] [PubMed] 
35. Polarz, S.; Landsmann, S.; Klaiber, A. Hybrid surfactant systems with inorganic constituents. Angew. Chem. Int. Ed. 2014, 53, 946-954. [CrossRef] [PubMed]

36. Nisar, A.; Wang, X. Surfactant-encapsulated polyoxometalate building blocks: Controlled assembly and their catalytic properties. Dalton Trans. 2012, 41, 9832-9845. [CrossRef] [PubMed]

37. Ito, T. Inorganic-organic hybrid surfactant crystals: Structural aspects and functions. Crystals 2016, 6, 24. [CrossRef]

38. Kobayashi, J.; Kawahara, R.; Uchida, S.; Koguchi, S.; Ito, T. Conductive Hybrid Crystal Composed from Polyoxomolybdate and Deprotonatable Ionic liquid Surfactant. Int. J. Mol. Sci. 2016, 17, 994. [CrossRef]

39. Misawa, T.; Koguchi, S.; Niwa, K.; Kinoshita, Y.; Uchida, S.; Ito, T. Conductive hybrid crystal composed of polyoxovanadate and deprotonatable ionic liquid surfactant. Inorg. Chem. Commun. 2018, 96, 24-29. [CrossRef]

40. Jiang, Y.; Liu, S.; Li, S.; Miao, J.; Zhang, J.; Wu, L. Anisotropic ionic liquids built from nonmesogenic cation surfactants and Keggin-type polyoxoanions. Chem. Commun. 2011, 47, 10287-10289. [CrossRef]

41. Wang, K.; Zhuang, R. Ionic liquids of imidazolium salts comprising hexamolybdate cluster: Crystal structures and characterization. Inorg. Chim. Acta 2017, 461, 1-7. [CrossRef]

42. Kobayashi, J.; Misawa, T.; Umeda, C.; Isono, T.; Ono, S.; Naruke, H.; Okamura, Y.; Koguchi, S.; Higuchi, M.; Nagase, Y.; et al. Controlled introduction of metal cations into polymerizable ionic liquid-polyoxomolybdate hybrid crystals. CrystEngComm 2019, 21, 629-636. [CrossRef]

43. Ito, T.; Otobe, S.; Oda, T.; Kojima, T.; Ono, S.; Watanabe, M.; Kiyota, Y.; Misawa, T.; Koguchi, S.; Higuchi, M.; et al. Polymerizable ionic liquid crystals comprising polyoxometalate clusters toward inorganic-organic hybrid solid electrolytes. Polymers 2017, 9, 290. [CrossRef] [PubMed]

44. Ito, T.; Kiyota, Y.; Oda, T.; Watanabe, M.; Ono, S.; Oda, Y.; Misawa, T.; Isono, T.; Otobe, S.; Okamura, Y.; et al. Highly conductive polymer electrolytes constructed from polymerizable ionic liquid and inorganic cluster. Trans. Mater. Res. Soc. Jpn. 2019, 44, 101-107. [CrossRef]

45. Otwinowski, Z.; Minor, W. Processing of X-ray diffraction data collected in oscillation mode. Methods Enzymol. 1997, 276, 307-326. [PubMed]

46. CrysAlisPro ver. 1.171.39.46; Rigaku Corporation: Oxford, UK, 2016.

47. Sheldrick, G.M. SHELXT-Integrated space-group and crystal structure determination. Acta Crystallogr. Sect. A 2015, 71, 3-8. [CrossRef] [PubMed]

48. Sheldrick, G.M. A short history of SHELX. Acta Crystallogr. Sect. A 2008, 64, 112-122. [CrossRef] [PubMed]

49. CrystalStructure 4.3; Rigaku Corporation: Tokyo, Japan, 2019.

50. Klemperer, W.G.; Shum, W. Synthesis and interconversion of the isomeric $\alpha$ - and $\beta-\mathrm{Mo}_{8} \mathrm{O}_{26}{ }^{4-}$ ions. J. Am. Chem. Soc. 1976, 98, 8291-8293. [CrossRef]

51. Himeno, S.; Niiya, H.; Ueda, T. Raman studies on the identification of isopolymolybdates in aqueous solution. Bull. Chem. Soc. Jpn. 1997, 70, 631-637. [CrossRef]

52. Cruywagen, J.J. Protonation, oligomerization, and condensation reactions of vanadate(V), molybdate(VI), and tungstate(VI). Adv. Inorg. Chem. 1999, 49, 127-182.

53. Ito, T.; Mikurube, K.; Abe, Y.; Koroki, T.; Saito, M.; Iijima, J.; Naruke, H.; Ozeki, T. Hybrid inorganic-organic crystals composed of octamolybdate isomers and pyridinium surfactant. Chem. Lett. 2010, 39, 1323-1325. [CrossRef]

54. Mikurube, K.; Hasegawa, K.; Matsumoto, T.; Kobayashi, J.; Naruke, H.; Ito, T. Isomerization-induced introduction of metal cations into polyoxomolybdate-surfactant hybrid crystals. Inorg. Chem. Commun. 2016, 73, 45-48. [CrossRef]

55. Rocchiccioli-Deltcheff, C.; Fournier, M.; Franck, R.; Thouvenot, R. Vibrational investigations of polyoxometalates. 2. Evidence for anion-anion interactions in molybdenum(v1) and tungsten(v1) compounds related to the Keggin structure. Inorg. Chem. 1983, 22, 207-216. [CrossRef]

56. Otobe, S.; Kiyota, Y.; Magira, S.; Misawa, T.; Fujio, K.; Naruke, H.; Uchida, S.; Ito, T. Conductive inorganic-organic hybrid layered crystals composed of Keggin-type polyoxotungstates and a heterocyclic surfactant. Eur. J. Inorg. Chem. 2019, 2019, 442-447. [CrossRef]

57. Nyman, M.; Ingersoll, D.; Singh, S.; Bonhomme, F.; Alam, T.M.; Brinker, C.J.; Rodriguez, M.A. Comparative study of inorganic cluster-surfactant arrays. Chem. Mater. 2005, 17, 2885-2895. [CrossRef] 
58. Nyman, M.; Rodriguez, M.A.; Anderson, T.M.; Ingersoll, D. Two structures toward understanding evolution from surfactant-polyoxometalate lamellae to surfactant-encapsulated polyoxometalates. Cryst. Growth Des. 2009, 9, 3590-3597. [CrossRef]

59. Bridgeman, A.J.; Cavigliasso, G. Electronic structure of the $\alpha$ and $\beta$ isomers of $\left[\mathrm{Mo}_{8} \mathrm{O}_{26}\right]^{4-}$. Inorg. Chem. 2002, 41, 3500-3507. [CrossRef] [PubMed]

60. Bridgeman, A.J.; Cavigliasso, G. A comparative investigation of structure and bonding in Mo and W $\left[\mathrm{TeM}_{6} \mathrm{O}_{24}\right]^{6-}$ and $\left[\mathrm{PM}_{12} \mathrm{O}_{40}\right]^{3-}$ heteropolyanions. J. Phys. Chem. A 2003, 107, 6613-6621. [CrossRef]

(C) 2019 by the authors. Licensee MDPI, Basel, Switzerland. This article is an open access article distributed under the terms and conditions of the Creative Commons Attribution (CC BY) license (http://creativecommons.org/licenses/by/4.0/). 